\title{
PERAN FORUM MEDIASI \\ DALAM MEMINIMALISIR KONFLIK \\ DI KALIMANTAN BARAT
}

\author{
Amalia Irfani
}

\begin{abstract}
ABSTRAK
Kalimantan Barat merupakan satu dari sedikit provinsi di Indonesia yang memiliki historis panjang berkaitan dengan ketidaharmonisan etnis. Meminimalisir konflik tidak hanya dilakukan oleh pemerintah, tetapi juga oleh Lembaga, Forum non formal yang berdiri atas prakarsa masyarakat atau individu. Forum Mediasi adalah salah satunya. Berdiri kerena keprihatinan Konflik Komunal yang selalu terjadi berulang. Tulisan ini mengkaji sedikit tentang peran Forum Mediasi dalam menangani konflik di Kalimantan Barat.
\end{abstract}

Kata Kunci : Peran Forum Mediasi, Konflik, Kalimantan Barat

\section{A. Latar Belakang}

Dalam kajian IImu SosiologiKomunikasi, salah satu upaya untuk meminimalisir konflik ataupun kekerasan adalah melalui pendekatan mediasi. Mediasi selama ini dipercaya mampu menjadi solusi penyelesaian konflik karena dianggap lebih demokratis dan dapat diterima dibandingkan dengan metode lainnya. Mediasi meletakkan pihak yang berkonflik pada posisi sama atau setara, tidak berat sebelah, tetapi pada posisi tengah atau netral. Beberapa konflik komunal yang pernah terjadi di Pulau Kalimantan khususnya di Kalimantan Barat (Kalbar), berhasil diredam melalui mediasi yang biasanya difasilitasi oleh pemerintah.Pemerintah sebagai perpanjangan hukum, memiliki hak dan kewajiban untuk menyelesaikan konflik, hal ini terkait dengan kenyamanan/kesejahteraan, keamanan masyarakat lainnya.

Konflik dapat dipahami sebagai proses sosial dimana masing-masing pihak yang berinteraksi berusaha untuk saling menghancurkan, menyingkirkan, mengalahkan karena berbagai alasan seperti rasa permusuhan. Adapun akar permasalahan atau sebab musabab konflik diantaranya : Pertama, perbedaan antar-perorangan atau antar-kelompok, 
yang acap kali menimbulkan benturanbenturan antar individu maupun antar kelompok. Kedua, perbedaan kebudayaan yang berpengaruh pada perbedaan kepribadian seseorang atau kelompok sebab karakter kebudayaan akan berpengaruh dalam membentuk karakter kepribadian manusia dalam kehidupan sosialnya. Ketiga, bentrokan antarkepentingan. Bentrokan atau benturan kepentingan ini berlatar belakang dari pertentangan. Keempat, perubahanperubahan sosial yang meliputi perubahan nilai-nilai dan norma-norma sosial. Dalam setiap perubahan ini akan terdapat dua sikap kelompok manusia akan perubahan itu sendiri, yaitu menerima perubahan dan menolak perubahan. (Elly M.SetiadiUsman Kolip, 2010 : 91).

Dalam http://id.wikipedia.org/wiki/ Mediasi beberapa alasan mediasi sebagai alternatif penyelesaian sengketa di Indonesia: 1). Faktor Ekonomis, dimana mediasi sebagai alternatif penyelesaian sengketa memiliki potensi sebagai sarana untuk menyelesaikan sengketa yang lebih ekonomis, baik dari sudut pandang biaya maupun waktu.2). Faktor ruang lingkup yang dibahas, mediasi memiliki kemampuan untuk membahas agenda permasalahan secara lebih luas, komprehensif dan fleksibel. 3). Faktor pembinaan hubungan baik, dimana mediasi yang mengandalkan cara-cara penyelesaian yang kooperatif sangat cocok bagi mereka yang menekankan pentingnya hubungan baik antar manusia (relationship), yang telah berlangsung maupun yang akan datang.

Karena sifatnya urgent dan fleksibel mediasi ${ }^{1}$ adalah solusi. Sehingga tidak mengherankan kehadiran forumforum mediasi seperti Forum Mediasi Kalimantan Barat adalah kebutuhan, mengingat tingginya sensitifitas etnis di Kalimantan Barat selain peran sentral dari pemerintah, seperti TVRI atau RRI. Hal ini diperkuat oleh kenyataan bahwa beberapa kelompok etnik yang bermukim di Kalbar sekarang telah memiliki wilayah kekuasaan (teritori) tersendiri, misalnya Kabupaten Sambas menjadi teritori Melayu Sambas dan Kabupaten Pontianak menjadi teritori Melayu Mempawah, Bengkayang teritori Dayak Bekati, Landak teritori Dayak Kanayatn, Sekadau teritori Dayak Mualang, Melawi teritori Dayak Keninjal dan Melayu Pinoh, Kayong Utara teritori Melayu Kayong. Adapun di Kawasan kabupaten seperti Sintang sedang berlangsung perjuangan

\footnotetext{
${ }^{1}$ Banyak hal yang perlu dipertimbangkan ketika, kita memilih jalur mediasi sebagai cara untuk menyelesaikan konflik yang dihadapi. Hal ini terkait dengan keterampilan mediator yang hendaknya dapat membantu pihak-pihak yang berkepentingan dengan menemukan jalan dan persetujuan yang dapat diterima. Apapun tindakan yang dilakukan mediator ketika berinteraksi, bekerjasama, dan mempengaruhi orang lain perlu mempertimbangkan posisi dan peran yang harus dimainkan.
} 
Dayak Ketungau untuk membentuk kabupaten sendiri. Di kabupaten Kapuas Hulu Dayak Iban, Taman, Kantu dan Suhaid sedang berlomba-lomba pula memekarkan kabupaten baru. Di Kabupaten Ketapang saat ini sedang berlangsung perjuangan Dayak Simpang,dan Dayak Keriau untuk mendirikan kabupaten baru. Di kabupaten Sanggau sedang berlangsung perjuangan Dayak Bidayuh dan Dayak Tayan untuk mendirikan kabupaten baru.

Ada dua hal yang dapat dapat penulis uraikan, Pertama, konflik yang melibatkan etnik Dayak terjadi mulai tahun 1966-1997. Pada masa ini etnik Dayak disingkirkan dari kekuasaan politik dan mereka korban hegemoni pihak yang berkuasa ketika itu. Kedua, sejak tahun 1999, etnik Dayak tidak berkonflik lagi, pada masa ini yang terlibat konflik adalah etnik Melayu. Etnik Melayu berkonflik karena mereka merasa terancam. Pada level pemerintahan Provinsi mereka tersingkir, sehingga secara politik mereka kalah bahkan terhegemoni oleh etnik Dayak. (http://kristianusatok.blogspot.com/ 2012/03/hegemoni-etnik-di-kalimantanbarat.html)

\section{B. Mediasi sebagai Solusi Alternatif Penyelesaian Konflik Komunal}

Konflik muncul ketika dua orang atau lebih dalam sebuah kelompok merasa bahwa nilai-nilai yang mereka anut termasuk harapan mereka bertentangan satu sama lain baik dimasa sekarang maupun dimasa depan (Tillet :1991 : 4). Brandon dan Robertson (2007 : 15) juga menjelaskan secara lebih mendetail pihak yang berkonflik yaitu intrapersonal, intra-group dan inter-group. Intrapersonal adalah konflik yang timbul diantara dua atau lebih orang. Sementara intra-group berarti konflik dalam kelompok atau tim dan inter-group ialah konflik yang sering terjadi antar kelompok. Penyebab terjadinya konflik sosial, diklasifikasikan sebagai berikut :

\section{Perbedaan Individu}

Dalam diri setiap manusia memiliki karakteristik yang khas dan unik, dimana keunikan yang dimiliki menjadi pembeda antara manusia satu dengan manusia yang lain. Melalui perbedaan karakter tersebut memungkinkan terjadinya perbedaan pandapat dan sudut pandang dalam menilai sesuatu, oleh karenanya akan memungkinkan terjadinya pertentangan dan ketidakselarasan dalam interaksi yang dilakukan, hal inilah yang menimbulkan konflik. Namun sesungguhnya perbedaan yang dimiliki oleh setiap individu dalam suatu masyarakat tidak harus menjadi faktor pemicu konflik, sebaliknya, perbedaan yang ada bisa menjadi pelengkap untuk 
saling mengisi kekurangan masingmasing orang yang terlibat dalam proses sosial tersebut.

\section{Perbedaan Latar Belakang Kebudayaan}

Setiap masyarakat pastilah memiliki kebudayaan yang berbeda dengan kebudayaan masyarakat lain. Hal ini disebabkan kebudayaan tersebut berbeda pada tempat dan kondisi tertentu.Dalam kehidupan yang lebih luas, tiap-tiap kelompok kebudayaan memiliki nilai-nilai dan norma-norma sosial yang berbedabeda ukurannya sesuai dengan kebutuhan masyarakat setempat. Perbedaan - perbedaan inilah yang memungkinkan terjadinya konflik sosial.Hal ini disebabkan kriteria tentang baik buruk, pantas atau tidak pantas maupun berguna atau tidak bergunanya sesuatu, baik itu berupa benda fisik maupun nonfisik berbeda-beda menurut pola pikir masing-masing yang didasarkan pada latar belakang budaya yang dianut.

\section{Perbedaan Kepentingan}

Setiap manusia pastilah memiliki kepentingan, dan kepentingan pada tiap individu pastilah berbeda-beda.Perbedaan kepentingan pada masing-masing memungkinkan munculnya konflik.Konflik akibat adanya perbedaan kepentingan dapat menyangkut bidang politik, ekonomi, sosial maupun budaya, dapat pula terjadi antar kelompok ataupun antar kelompok dengan individu.

\section{Perubahan - perubahan Nilai yang Cepat}

Perubahan nilai terjadi pada setiap masyarakat dimana nilai-nilai sosial, nilai kebenaran, kesopanan, maupun nilai matrial suatu benda mengalami perubahan, sehingga perubahan adalah hal yang lazim terjadi. Namun, apabila perubahan nilai berlangsung dengan cepat dan mendadak, maka akan menimbulkan guncangan terhadap proses-proses sosial dalam masyarakat, bahkan dapat terjadi perubahan karena dianggap mengacaukan tatanan kehidupan.

Menurut Robbin dan Judge (2011: 457-465) ada lima tahapan dalam konflik; pertama potensi oposisi atau ketidakcocokan, kedua pengamatan dan personalisasi, ketiga keinginan atau niat, keempat tingkah laku dan kelima adalah hasil. Secara garis besar tahapan konflik menurut Robbin dan Judge ini dapat dijelaskan secara singkat bahwa pertama konflik muncul karena terjadi perbedaan pandangan. Perbedaan pandangan ini harus menjadi sebuah perbedaan pribadi. Sebagai contoh A dan B berdebat mengenai sesuatu hal, namun perdebatan $A$ dan $B$ ini jika belum sampai pada tahap 
keterlibatan secara emosional maka belum menjadi sebuah konflik. Dari keterlibatan emosional tersebut kemudian konflik memasuk tahap keinginan atau niat. Pada tahap ini pihak yang berselisih akan masuk dalam tahap keinginan berkompetisi untuk memenangkan konflik guna mendapatkan kepuasaan pribadinya ataupun keinginan kelompok. Dalam proses ini juga bisa terjadi sebaliknya yaitu berusaha mencegah lebih dalam terlibat konflik dengan mengacuhkan konflik tersebut. Pada tahap ketiga pula ada kemungkinan pula bahwa pihak yang berselisih berusaha mengalah untuk tidak terlibat dalam konflik dengan mendukung pendapat pihak yang berlawanan dengannya atau ada kemungkinan pula melakukan tahap kompromi sehingga tidak ada pihak yang dirugikan atau dikalahkan.Tahap keempat yang merupakan tingkah laku berarti dalam tahap ini mulai dilakukan suatu perbuatan untuk melawan baik berupa pernyataan ataupun perbuatan. Demonstrasi, perang atau kekacauan terjadi pada tahap keempat ini.Pada tahap kelima konflik adalah hasil dari konflik itu sendiri.Ada dua kemungkinan hasil dari sebuah konflik, menaikkan kualitas kerja kelompok atau menurunkan kualitas kerja kelompok.

Akibat dari tidak adanya budaya malu, kerusuhan (konflik) demi kerusuhan yang banyak menimbulkan korban menjadi hal yang biasa-biasa saja (Zulfydar Zaidar Mochtar, 2009 : 17). Mediasi dipandang sebagai cara penyelesaian paling optimal sebab diselesaikan atas kesepakatan antar kedua belah pihak. Hal ini sesuai dengan Undang-undang 39 tahun 1999 tentang hak azasi manusia, kewajiban perlindungan, pemajuan, penegakan dan pemenuhan Hak azasi manusia sesuai pasal 28 I ayat (4) Undang-undang Dasar 1945 dan pasal 71 dan 72 Undangundang 39 Tahun 1999 tentang Hak azasi manusia dilaksanakan oleh pemerintah atau negara.

Untuk menyelesaikan kewajiban tersebut, pemerintah dan masyarakat dapat berupaya menggunakan cara legitasi dan non legitasi. Disebut legitasi karena penyelesaiannya mempunyai proses peradilan yaitu pengadilan negeri, peradilan tata usaha negara, pengadilan tinggi dan kasasi. Sedangkan non legitasi adalah penyelesaian sengketa diluar peradilan seperti arbiterasi, konsiliasi dan mediasi, dimana pihak ketiga atau lembaga swadaya masyarakat yang turut serta menyelesaikan sengketa (Zulfydar Zaidar Mochtar, 1999 : 36). 


\section{Konsep Mediasi Tradisional sebagai Solusi}

Mediasi dipilih sebagai solusi masalah sosial ditingkat strata bawah (akar rumput) sebab melibatkan pihak bertikai dari hati ke hati, tidak diintimidasi karena adanya kepentingan. Mediasi diawali dengan berbagai negosiasi untuk mencari titik temu masalah, walaupun belum ada standar baku mengenai isi kesepakatan. Kesepakatan yang dibuat oleh Forum Mediasi dinamakan mediasi Tradisional.

Mediasi tradisional (Zulfydar Zaidar Mochtar, 1999 : 43), adalah Mana yang bisa disepakati oleh kedua belah pihak, dapat disepakati terlebih dahulu tanpa paksaan dari hati ke hati dalam rangka memenuhi keinginan para pihak dan masyarakat dalam upaya memulihkan keadaan. Cara ini paling sederhana, siapapun dapat menggunakan mediasi tradisional tanpa dibatasi, karena konsepnya adalah bukan untuk membatasi. Kesepakatan mediasi tradisional menjadi lebih baik apabila terjadi pengakuan Pemerintah dan menjadi penting agar kondisi keamanan tetap terjaga. Beberapa tokoh masyarakat kota Pontianak, juga mengamini, bahwa mediasi adalah solusi terbaik dalam memecahkan masalah, menerima dengan ikhlash tanpa ada paksaan.
Lebih rinci, Zulfydar yang juga pendiri Forum Mediasi sekaligus mediator menjelaskan, mediasi diperlukan sebab kerusuhan di Kalimantan Barat selama ini pasca kerusuhan komunal tahun 1999, tidak pernah selesai, selalu berulangulang karena penyelesaian tidak sampai ke strata bawah (akar rumput). Kegelisahan itulah yang membuatnya merasa perlu membuat sebuah wadah, hatinya terpanggil untuk mendirikan sebuah sarana yang dapat membantu menyelesaikan masalah tidak dari luar saja, tetapi dari dalam. Ide yang muncul tahun 2000 pasca kerusuhan tahun 1999 akhirnya terealisasi tahun 2001-2002. Disadari atau tidak, persoalan sosial akar rumput pada dasarnya mempunyai muatan legitasi dan non legitasi. Namun persolan tersebut bisa dianggap selesai oleh para pihak atau masyarakat setempat dengan cara kesepakatan dengan mengikat suatu perjanjian, artinya masyarakat mengakui penyelesaian persoalan dengan cara bersepakat / kesepakatan, meskipun ada juga yang menentang cara ini karena dianggap melanggar hukum.

Konsep Mediasi Tradisional, Forum Mediasi Kalbar adalah :

1. Mencari kesepakatan yang bisa disepakati terlebih dahulu

2. Membutuhkan waktu untuk menjadi kesepakatan 
3. Pendekatan kebiasaan atau tradisi

4. Pendekatan kehidupan kebudayaan

5. Pendekatan keagamaan

6. Pendekatan dengan garis-garis kelompok atau fraksi

Dalam mediasi tradisional mediasi dapat berjalan sesuai dengan yang diinginkan, diperlukan :

1. Batasan jumlah mediator yang ditunjuk

2. Keterwakilan

3. Menguasai dan mengerti persolan

4. Diakui, ditunjuk atau dipilih oleh para pihak

5. Bahasa yang disampaikan dimengerti oleh para pihak

6. Membuat renacana kerja mediasi hingga kesepakatan (diterima/tidak diterima).

Mediasi tradisional disini yang ditawarkan Zulfydar Zaidar terasa hambar apabila persoalan penyelesaian kesepakatan sosial tidak diikuti strata bawah, menengah, atas atau para intelektual karena akan terasa mubazir. Tawaran kesepakatan mediasi tradisional selalu menjaga keseimbangan sosial yang terukur. Alasannya fenomena yang terjadi pada saat ini mempunyai hubungan yang saling terkait, artinya mediasi diikuti dan dilaksanakan oleh semua lapisan yang selalu berkorelasi dari akar-rumput, tokoh politik, tokoh masyarakat, anggota
DPR/MPR, pimpinan negara, pimpinan politik, aparat negara, mantan presiden, wakil presiden dan mantan tokoh politik yang mempunyai pengaruh dapat berkumpul membicarakan solusi kedamaian untuk bangsa Indonesia.

$$
\text { Hal menarik dalam mediasi }
$$
tradisional adalah, adanya unsur spiritual. Zulfydar dalam bukunya Mediasi Tradisional (1999 : 48) mengutip pendapat Syaikh Najm al-Din Kubra dalam bukunya Meditasi secara sufi, "ada" perjalanan spiritual untuk menyingkirkan segenap hijab yang menghalangi penglihatan kalbu dan cahaya sifat-sifat ilahi dalam kalbu sang penempuh jalan spiritual. Ini bermaksud bahwa, jalan penyelesaian ditempuh tidak hanya mengandalkan pikiran dan tenaga, tetapi juga meminta kemudahan dari sang Khaliq. Forum mediasi menamakan ini sebagai religius dalam mediasi; campur tangan Allah SWT menjadi penentu. Zulfydar yang juga mediator Forum Mediasi mengungkapkan campur tangan atau perantara Allah SWT dapat dibuktikan dengan bisikan La ila Haillaallah, out put yang dihasilkan adalah positif.

Bisikan La ila Haillaallahadalah salah satu pembuka dalam perjalanan mediasi. Hal ini dilakukan oleh Forum Mediasi pada saat proses mediasi komunitas Melayu-Madura, namun tidak langsung dapat diketahui atau dapat 
disimpulkan namun harus melalui proses waktu, perjalanan dan pembuktian dengan memindahkan konsep spiritual, religius, dan budaya lalu ditransfer dalam bentuk teoritis yang dihubungkan dengan fakta lapangan lalu diuji konsep tersebut. Mediator dituntut professional, ikhlash dan berserah diri sepenuhnya kepada Allah SWT.

Selain pengucapan La ila Haillaallah, sebagai seorang Muslim lafadz Bismillahirahman nirohim juga tidak dapat terpisah dari kalimah $L a$ ila Haillaallah, sadaratau tidak kemampuan mediator memahami kondisi lapangan merupakan bentuk campur tangan dari Allah SWT.

\section{Peran Sosial Forum Mediasi Kalbar}

\section{Keberadaan Forum Mediasi}

$\begin{array}{lrr}\text { Forum mediasi } & \text { merupakan } \\ \text { sebuah lembaga } & \text { sosial } \\ \text { kemasyarakatan } \quad \text { yang } & \text { khusus }\end{array}$
menangani konflik/kerusuhan etnis di Kalimantan Barat. Berdiri pada tahun 2000, dan diprakarsai oleh pemuda asal Kalbar Zulfydar Zaidar Mochtar. Kegelisahan karena melihat kerusuhan berdarah yang tidak pernah selesai, dan selalu menimbulkan kerusuhan lain yang sifatnya komunal, berkelanjutan, dan semakin beringas. Ibrahim Alqadrie Profesor Sosiologi pada Fakultas IImu Sosial dan IImu Politik
(FISIP) Universitas Tanjungpura mencatat, sejak tahun 1963 telah terjadi 12 kali pertikaian antar anggota kelompok komunitas, yaitu :Pertama, 1 (satu) kali antara anggota komunitas Dayak dengan komunitas Tionghoa yang terjadi pada beberapa kawasan pedalaman di Kabupaten Sambas, Pontianak dan Kabupaten Sambas, Pontianak, dan Kabupaten Sanggau. Kedua, 9 (Sembilan) kali antara anggota komunitas Dayak pedalaman dengan komunitas Madura pedalaman yang terjadi pada beberapa kawasan pedalaman di Kabupaten Sambas (sekarang Kabupaten Bengkayang), sebagian besar kawasan pedalaman di Kabupaten Pontianak (termasuk di Kabupaten Landak) dan pada beberapa kawasan di Kabupaten Sanggau.

Ketiga, 1 (satu) kali antara anggota komunitas Melayu Sambas yang berlangsung di berbagai kawasan Kabupaten Sambas (pertikaian ini tidak termasuk pada kawasan di Kabupaten Bengkayang). Keempat, 1 (satu) antara komunitas Melayu campuran dengan komunitas Madura yang terjadi di Kota Pontianak, khususnya disekitar Jembatan Kapuas. Pertikaian terakhir di tahun 2000, 
berlangsung selama 3 (tiga) hari dan menelan korban 2 (dua) orang. ${ }^{2}$

Atas dasar keprihatinan inilah membuat Zulfydar tergerak mendirikan forum mediasi. ${ }^{3}$ Sesuai namanya, forum ini memediasi pihak yang berselisih agar bisa damai. Bambang $W$. Soeharto dalam bukunya Menangani Konflik di Indonesia ${ }^{4}$ mengatakan ada lima kategori konflik di Indonesia, dan Kalimantan Barat, Aceh, Papua, Maluku, dan Poso adalah provinsi yang masuk sebagai provinsi konflik berdimensi politik. Gentingnya situasi keamanan Kalimantan Barat mendorong banyak pihak untuk mencari solusi penyelesaian bersifat menguntungkan, tidak berat sebelah, sehingga ketika forum mediasi tampil didukung oleh banyak pihak, mulai dari pemerintah hingga masyarakat yang mengharapkan perdamaian di bumi khatulistiwa.

Pertikaian terakhir di Kalimantan Barat, yakni antara komunitas Melayu dengan Madura

\footnotetext{
${ }^{2}$ Presentasi pada Pelatihan Da'i Perbatasan dengan tema Memahami Fenomena Konflik Berbasis Sumber Daya Alam diselenggarakan oleh Sekolah Tinggi Agama Islam Negeri (STAIN) bekerjama dengan EC-Indonesia FLEGT Support Project Kalbar di Wisma Merdeka Pontianak 8 April 2006.

${ }^{3}$ Tim Forum Mediasi Kalimantan Barat terdiri dari : Zufydar Zaidar Mochtar, Iwan Kurniawan, Uray Mauritzio, Wendy Japandri, dan Wan Herman Setiawan.

${ }^{4}$ www.merdeka.com
}

merupakan bukti dari peran yang telah berhasil dimainkan oleh Forum Mediasi. Perencanaan matang mulai dari strategi, pembentukan tim lapangan dilakukan oleh forum mediasi dari nol. Alasan pembentukan tim adalah untuk memudahkan upaya rekonsiliasi, keterwakilan darah keturunan tidak hanya karena didasari kekuatan yang tampak dalam keseharian, kejadian atau konsep teoritis, tetapi dimungkinkan keterlibatan ghoibiah sesuai arah perjalanan. Kekuatan yang tidak dapat diungkapkan, namun kekuatan tersebut berpengaruh besar dalam perjalanan rekonsiliasi.

Rekonsiliasi tidak akan pernah bisa berjalan tanpa dukungan semua pihak, seperti ungkapan "besi panas saja tidak langsung dingin perlu proses dan waktu", begitu pula dengan rekonsiliasi etnis Melayu-Madura. Mengutip pendapat Timo Kivimaki dalam Zulfydar (2002 : 26-27) tentang beberapa usaha negosiasi yang bisa dilakukan dalam rangka mencapai perdamaian. Menurutnya, seperti yang telah dilakukan oleh Program on Negotiation dari Harvard University, telah meneliti betapa pentingnya hubungan antara juru runding dengan pihak yang diwakilinya. Tanpa pendekatan, hasil yang diperoleh dari 
perundingan akan sangat sulit ditegakkan dan dilaksanakan. Proyek Harvard mengidentifikasi 4 prinsip untuk mencapai sukses :

1. Memisahkan orang dari masalah

2. Konsentrasi pada kepentingan dalam perundingan, bukan pada posisi

3. Menciptakan pilihan-pilihan untuk manfaat kedua belah pihak, bukan mengambil hal-hal yang sudah jelas.

4. Bersikeras menggunakan kriteria yang objektif untuk menyelesaikan, menyangkut distribusi dan untuk yang lain-lain.

Peran yang dimainkan oleh Forum Mediasi walau belum terlalu dikenal luas oleh masyarakat namun diancungi jempol oleh beberapa warga asli Kalimantan Barat yang menyimak dari awal pertikaian di Kalbar dari tahun 1963 hingga tahun 2000. Mereka menilai, seperti namanya forum ini diharapkan selalu mampu diandalkan untuk memediasi jika terjadi gesekan antar etnis, independent, serta netral.

\section{Peran Mediator}

Mediasi konflik dapat juga diartikan penyelesaian masalah diluar pengadilan, jika di pengadilan peran sentral pada hakim dikeputusan akhir, maka pada mediasi konflik, mediator adalah ujung tombak keberhasilan. Tugas mediator adalah melaksanakan kesepakatan untuk mencapai perdamaian yang diharapkan. Apabila kesepakatan awal tidak terpenuhi maka proses menuju perdamaian tertutup pula dalam upaya memenuhi perdamaian secara menyeluruh. Menyeluruh dimaksudkan disini sesuai keinginan para pihak termasuk pihak lain yang dirugikan. Mediator selalu mencoba untuk menggunakan dan memanfaatkan momentum atau waktuwaktu dan cara yang tepat. Cara kerja mediator selalu berbeda-beda mengikuti besar-kecilnya masalah.Tim tidak boleh bekerja tergesa-gesa, karena bisa jadi memperlambat proses mediasi. Mediasi tradisional tidak harus menunggu pemerintah atau aparat untuk menyelesaikan sengketa.

Zulfydar menuturkan, siapa saja bisa saja menjadi mediator, tetapi lebih baik mediator memiliki jaringan kuat dengan pihak-pihak tingkat atas hingga bawah (1. TNI, POLRI, dan satuan POL PP, 2. Aparat Pemerintah, 3. Masyarakat Pemangku adat-Pemuka Agama, 4. Kepala Rukun warga dan Rukun Tetangga), pandai berkomunikasi dan ikhlash. Ukuran kerja mediator bukan karena latar belakang pendidikan tinggi, namun pada kemampuan menawarkan draft 
atau konsep solusi perdamaian. Para

pihak pun dalam mengukur keberhasilan seorang mediator jika hasil kesepakatan berimbas positif dan dapat dirasakan langsung. Berikut beberapa pengertian mediator (mediasi tradisonal) (Zulfydar, 2009 : 181) :

a. Orang yang disetujui/ditunjuk oleh para pihak untuk melangsungkan perdamaian

b. Mempunyai latar belakang minimal dikenal oleh masyarakat berkonflik, dengan tujuan agar mediasi lebih cepat dan berjalan lebih mengarah kesepakatan

c. Mampu meninggalkan latarbelakang kepentingan saat melakukan proses mediasi

d. Tidak berpihak dalam melakukan proses mediasi

e. Tidak berpihak dalam memutuskan kesepakatan

f. Bersifat independen

g. Bekerja secara professional

h. Mampu menggiring pra kesepakatan saat kesepakatan dan pasca kesepakatan

i. Mengerti dan menguasai persoalan

j. Menguasai bahasa yang digunakan

$\mathrm{k}$. Menguasai bahasa isyarat

I. Menggunakan kalimat bahasa yang sederhana agar mudah dimengerti para pihak

m. Memahami etika, adat dan budaya n. Mempunyai prediksi yang tajam

o. Siap mengalami dan menerima resiko

Sifat mediator diklasifikasikan :

a. Dapat dipercaya

b. Mampu membuat program kerja

c. Bertanggung jawab akan konsep yang ditawarkannya

d. Mampu menampung aspirasi

e. Mampu membuktikan fakta dan bukti untuk dimusyawarahkan

f. Mengerti dan menguasai persoalan

g. Mampu menghindari kebekuan dalam proses kesepakatan

h. Netral dengan azas keseimbangan

i. Mampu memberikan proses dan waktu bernegoisasi

Tujuan Mediator adalah :

a. Mendudukan kembali masalah yang dihadapi oleh para pihak

b. Memperjelas kasus yang akan disepakati

c. Memperjelas kasus yang tidak disepakati

d. Menguji kesiapan para pihak bermufakat

e. Dapat memberikan arah atau pendekatan penyelesaian

f. Memberikan peluang untuk melaksanakan kesepakatan dengan cara ritual atau bentuk lainnya 
g. Mampu memberikan gambaran akibat sebelum, saat dan sesudah kesepakatan mediator :

Target yang harus dicapai

a. Menciptakan rasa aman

b. Menghentikan perbedaan

C. Menghentikan permusuhan

d. Menghentikan peperangan atau pertikaian

e. Membuat kesepakatan

f. Menciptakan keadaan sosial yang kondusif

\section{E. Strategi Forum Mediasi}

Banyak jalan menuju Roma, tidak ada yang tidak mungkin jika Allah berkenan, menjadi inspirasi Forum Mediasi untuk menyelesaikan masalah sosial yang disebut Zulfydar pertikaian berdarah. Jika sebelumnya pada kasuskasus pertikaian di Kalimantan Barat penyelesaian bersifat sementara, ${ }^{5}$ belajar

\footnotetext{
${ }^{5}$ Bersifat sementara, dipahami oleh beberapa masyarakat sebagai proses luar yang tidak melibatkan unsur bawah (tidak sampai akar rumput), masalah hanya diredam sementara, namun siap kapan dan dimanapun untuk meledak. Pertikaian Melayu vs Madura diawal tahun 2000 juga disebut Konflik masal tidak akan terjadi secara serta merta, melainkan selaludiawali dengan adanya potensi yang mengendap di dalam masyarakat, yang kemudian dapat berkembang memanas menjadi ketegangan dan akhirnya memuncak pecah menjadi konflik fisik akibat adanya faktor pemicu konflik. Oleh karenanya dalam rangka penanggulangan konflik, yang perlu diwaspadai bukan hanya faktor-faktor yang
}

dari pengalaman yang ada, Zulfydar merasa harus ada paradigma baru pemecahan konflik etnis di Kalimantan Barat, walaupun sebenarnya tidak dapat dielakkan potensi konflik selalu ada, setidaknya ada usaha meminimalisir konflik dengan kepala dingin, tidak selalu menjurus pada pertikaia;n berdarah.

Strategi dalam usaha proses mediasi pun dilakukan, dimulai dari pembentukan tim, namun sebelum pembentukan tim, Zulfydar menemui Pangeran Winata Kesuma di Kota Sambas, untuk meminta izin, melaporkan rencana rekonsiliasi dan meminta saran atau pendapat Sultan Alwatzikhoebillah Sambas. Hal ini dilakukan karena pengaruh besar Pangeran Winata Kesuma, walaupun awalnya "cukup berat" mempersilahkan untuk melanjutkan upaya rekonsiliasi. Pangeran mengingatkan keadaan psikologis dan sosial masyarakat di Kabupaten Sambas karena perbedaan masih sangat mencolok dan beberapa etnis Madura keturunan di Kabupaten Sambas, mereka dilindungi masyarakat setempat.

Setelah mendapat persetujuan dari Pangeran Winata Kesuma, Zulfydar sebagai penggerak membentuk tim Mediasi, melibatkan pemuda-pemuda

dapat memicu konflik, namun juga yang tidak kalah pentingnya adalah faktor-faktor yang dapat menjadi potensi atau sumber-sumber timbulnya konflik. 
cakap, tidak berlatar belakang pemerintah, militer, atau terkait organisasi kenegaraan yang menurutnya mampu berada ditengah untuk menyelesaikan masalah "besar" Kalimantan Barat. Tim gabungan tersebut terdiri atas : Wendy Japandri keturunan Sambas, Iwan Kurniawan keturunan Raja Jogya ke dua, Uray Mauritzio keturunan SambasPadang, dan Wan Herman Setiawan keturunan Arab-Bugis. Ibarat mesin sudah mulai bergerak seluruh gerbong keikhlasan dan amanah tidak dapat dibendung lagi. Walau sempat muncul rasa khawatir terhadap kesiapan banyak pihak termasuk Pemerintah Daerah, yang berkosentrasi pada relokasi pengungsi Sambas.

Untuk mengorganisir pekerjaan, tim dibagi atas bidang masing-masing disesuaikan latar belakang pekerjaan dan kemampuan. Beberapa kelompok pekerjaan dibagi sesuai porsinya masingmasing :

1. Konsep Teoritis

2. Konsep Responden

3. Konsep Budaya

4. Konsep Spritual

5. Konsep Religius

6. Konsep Keamanan

7. Konsep Kebijakan

Fakta di lapangan yang didapat oleh Tim adalah, Melayu Sambas berkeinginan etnis Madura jangan dahulu pulang, tetap menunggu proses alami dan tidak dipaksakan. Agar berimbang selain melakukan observasi dilapangan, tim juga berkoordinasi dengan beberapa akademisi/pakar konflik untuk mendapatkan beberapa pertimbangan terkait dengan kompleksitas masalah. Tim pun (Zulfydar) menemui Gubenur Kalimantan Barat (H. Aspar Aswin, berpangkat terakhir Mayor Jenderal) untuk menawarkan konsep perdamaian mengatasi pertikaian Melayu SambasMadura. Konsep Teoritis dinamakan tim sebagai Konsep Dini, yakni sebuah konsep penyelesaian disesuaikan dengan fitrah manusia sebagai makhluk Tuhan (ghoib), makhluk sosial. ${ }^{6}$ Gubenur menyambut dengan baik, mendukung dan memberikan kemudahan dalam upaya menjalankan Konsep Dini.

Untuk mempertajam konsep teori, mediator selain melakukan pemantauan psikologis masyarakat kedua belah pihak, kemudian berdialog secara ghoibiah. Dialog ini selalu berbicara hal-hal yang strategis untuk kepentingan rekonsiliasi. Pembuktian percakapan dan pertanyaan dalam berkomunikasi dengan ghoibiah, tim dari dalam ikut menyaksikan dengan bertanya dan mendengarkan proses rekonsiliasi dan langkah-langkah yang harus dicapai. Pembuktian (saksi) ini

\footnotetext{
${ }^{6}$ Draft Terlampir
} 
menjadi penting, sebab dapat menjadi suatu rencana, konsep yang realistis dan efektif.Zulfydar menambahkan, pekerjaan ini walau penuh pro kontra syirik atau tidaknya. Namun, melalui berbagai rangkaian dialog panjang, hasil komunikasi setelah dihubungkan dengan fakta lapangan mampu menghasilkan konsep-konsep untuk program kerja bersifat skala prioritas.

Setelah pembentukkan tim, koordinasi lapangan, strategi tim adalah mengklasifikasi pengaduan masyarakat selain mencari akar masaah juga sebagai bentuk aspirasi yang diinginkan masyarakat. Mekanisme pengaduan sebagai berikut (Zulfydar, 2009 : 184) :

1. Pelapor menyampaikan masalah dihadapan petugas yang ditunjuk

2. Pelapor menyampaikan secara tertulis

3. Pelapor dapat melampirkan foto copy KTP sebagai identitas

4. Pelapor menandatangani kronologis yang telah diberikan

5. Pelapor merupakan masyarakat atau masyarakat adat tidak memahami bahasa cukup memberikan petunjuk lain/petunjuk lapangan secara langsung yang dapat dimengerti

6. Pelapor merupakan masyarakat atau masyarakat adat tidak mengerti masalah yang dihadapi namun merasa haknya dirampas. Laporan tersebut cukup memberikan simbol dengan mengikuti aturan adat setempat

7. Jika pelapor mewakili orang lain dapat secara tertulis diberikan surat kuasa

Strategi berikutnya adalah, menawarkan konsep perdamaian kepada para pihak yang bersengketa. Mediator harus mampu mendeteksi masalah. Bagian terpentingnya adalah menguji laporan kronologis dengan cara deteksi dini, akar masalah, masalah, dianalisa sebelum disimpulkan.

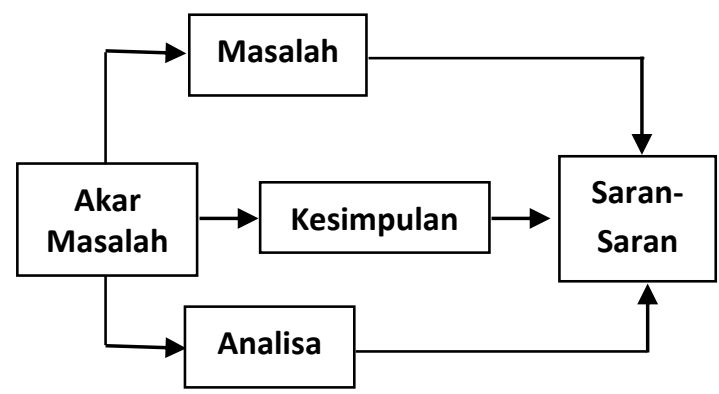

Setelah menganalisa masalah, maka didapatkan kesimpulan berupa draft untuk proses mediasi. Tahap selanjutnya adalah, mediator door to door menawarkan draft kesepakatan kepada para pihak yang dirasakan berkaitan langsung dengan pertikaian. Proses ini cukup alot dan memerlukan kesabaran. Tim Harus mampu berkomunikasi dengan baik sambil memperhitungkan akibat kesepakatan apakah berakses positif atau negatif yang ditimbulkan dari suatu kesepakatan, seperti : 
a. Masyarakat kedua belah pihak tidak sabar untuk saling bertemu

b. Masyarakat kedua belah pihak ingin berjalan sendiri-sendiri dalan upaya menyelesaikan masalah

c. Para pihak belum bisa menerima pertemuan karena belum ada sosialisasi

d. Tidak dihormatinya juru bicara atau pemimpin kelompok dalam suatu pertemuan.

Budaya berbeda antara Melayu dan Madura mengharuskan mediator juga mempersiapkan tata cara ritual, sebagai bentuk penghormatan selain acara seremonial. Tujuan kesepakatan adat dan budaya agar hubungan kebiasaan seharihari dalam suatu kehidupan beradat dan berbudaya dapat diterima dan menginspirasi untuk menciptakan kehidupan harmonis. Tata cara ritual dalam Mediasi Tradisional adalah :

a. Para pihak menunjuk perwakilan adat untuk pelaksanaan ritual

b. Mempersiapkan tata cara ritual secara hukum adat yang dapat diterima oleh kedua belah pihak

c. Mempersiapkan kelengkapan msuyawarah kesepakatan adat

d. Mempersiapkan alat-alat ritual adat

e. Membangun tempat peringatan atau membuat monumen peringatan dimana setelah para pihak sudah bersepakat melakukan persetujuan

Pendekatan kepada masyarakat pun menjadi bagian penting yang tidak dapat dianggap sepele dalam usaha rekonsiliasi, khususnya pendekatan kepada pemuka etnis. Zulfydar menjelaskan, ada beberapa cara mediator melakukan upaya pendekatan dengan para pihak, bisa tertutup atau terbuka tergantung kebutuhan dan keadaan pada saat itu. Mediasi Tradisional menuntut semua pihak untuk selalu terbuka, ikhlash dan berbesar hati : dapat mengikuti, dapat memahami, dapat memiliki, dapat menyetujui/tidak, dapat menyelesaikan, dan dapat mensosialisasikan (6 M).

Jika kesemua itu dapat berjalan dengan baik dari awal, maka perdamaian bukan suatu keniscayaan. Hal ini dibuktikan oleh Tim Forum Mediasi yang berhasil memediasi etnis Melayu dan etnis Madura. Pihak bertikai mau menerima kesepakatan dengan lapang dada, ikhlash dan tidak lagi saling menyalahkan.

Strategi yang dilakukan Forum Mediasi tidak serta merta mereda setelah perdamaian berhasil disepakati.Forum Mediasi, sama seperti lembaga kemasyarakatan lainnya, juga masih bekerja menggali hal baru untuk harmonisasi etnis di Kalbar. Seminar, 
lokakarya telah beberapa kali dilakukan, melibatkan elemen masyarakat, sebagai bentuk sosialiasi dan menyatukan visi. Pro kontra dalam sosialisasi menjadi masukan sekaligus pertimbangan Forum Mediasi Kalbar untuk melangkah ke depan.

\section{F. Kesimpulan}

Dari paparan diatas maka dapat disimpulkan :

1. Keberadaan Forum Mediasi Kalbar berakses positif, diterima oleh masyarakat multi etnis di Kalbar, dibuktikan dalam rekonsiliasi etnis Melayu dan Madura. Forum Mediasi mampu memediasi pertikaian, dendam, menjadi sebuah perdamaian.

2. Strategi yang dilakukan oleh Forum Mediasi mendamaikan etnis Melayu dan etnis Madura, berhasil dengan baik menciptakan Kalbar yang kondusif. Dimulai dari pembentukan tim kreatif, koordinasi dengan pihak yang dianggap kompeten dalam usaha menuju perdamaian, membuka pengaduan masyarakat untuk mengetahui sekaligus memahami masalah.

3. Konsep Mediasi tradisional yang ditawarkan Zulfydar, adalah konsep yang pas dengan kebutuhan/keinginan masyarakat Kalbar. Konsep Mediasi Tradisional paling sederhana, siapapun dapat menggunakan mediasi tradisional tanpa dibatasi, karena konsepnya adalah bukan untuk membatasi.Beberapa masyarakat kota Pontianak, juga mengamini, bahwa mediasi adalah solusi terbaik dalam memecahkan masalah, menerima dengan ikhlash tanpa ada paksaan.

\section{G. Daftar Pustaka}

Alqadrie, Syarif Ibrahim. 2008. Matahari Akan Terbit di Barat, Pontianak :Yayasan Insan Cita Kalimantan Barat

Cangara, Hafied. 2000. Pengantar IImu Komunikasi. Jakarta : PT. Raja Grafindo Persada

Fatmawati, 2011. Harmonisasi Antar Etnik Di Kalimantan Barat; Studi Etnografi Melayu dan Dayak.Pontianak : Stain Press

http://kristianusatok.blogspot.com/2012/03 /hegemoni-etnik-di-kalimantanbarat

Maleong, Lexy, J. 1990. Metode Penelitian Kualitatif. Bandung : PT. Remaja Rosdakarya

Mulyana, Deddy. 2003. IImu Komunikasi, Bandung: PT. Remaja Rosdakarya Mulyana, Edi, dan Rakhmat Jalaluddin. Editor. $1996 . \quad K o m u n i k a s i$ Antarbudaya, Bandung : PT. Remaja Rosdakarya. 
Purwasito, Andrik. 2003. Komunikasi

Multikultural, Surakarta

Muhammadiyah University Press.

Robbins, S.P \& Judge, 2011,

Organizational Behavior, Pearson

Education, New Jersey.u

Tillett, G \& French, B. 2006, Resolving Conflict, third edition, Oxford University Press, Melbourne.

Tillet, G 1991, Resolving Conflict: a Partical Approach, Sydney University Press, Sydney.

Amalia Irfani. 2011. Tesis. Fisip

Universitas Tanjungpura

Zulfydar Zaidar. 2007. Mediasi Tradisional (Melayu-Madura), Pontianak : PT. Romeo Mitra Grafika 